\title{
RESENHA LIVRO: ARQUIPÉLAGO GULAG
}

Jefson Jesus de Souza ${ }^{1}$

\section{SOLZHENITSYN, Aleksandr. ARQUIPÉLAGO GULAG. Ia edição. São Paulo: Editora Carambaia, 2019}

A crueldade, na história, tocou ápices durante $\mathrm{o}$ instável século XX. Principalmente, no tempo citado, a palavra dor foi bastante utilizada, afinal, aconteceram as duas piores guerras da humanidade onde milhões de pessoas perderam suas vidas nos campos negros de batalhas que se espalharam por vários cantos do mundo, e logo depois, com o fim da Segunda Guerra, quando pensávamos que a loucura daria finalmente lugar a razão, o mundo se tornou novamente refém do perigo com a Guerra Fria e a possibilidade de uma extinção nuclear. Mas bem, preste atenção, caro leitor, permita-me, gentilmente, contar uma história, uma pequena, mínima, história de um dos formidáveis capítulos do século $\mathrm{XX}$ onde a tal liberdade continuaria a ceder lugar ao autoritarismo que circulava equipado com violência e perversão. Discursarei sobre ilhas. Não das ilhas que tantas vezes foram refúgios de homens solitários. Não, não dessas ilhas. Citarei outras, dilacerantes, corruptíveis, macabras, espaços opressivos formados de gelo e terror. Sobre um conjunto de ilhas que formavam um arquipélago e que foram mencionadas num romance chamado "Arquipélago Gulag”. O romance, ele todo, um pólo de ferocidade que obteve influência de Tolstoi e de seu, grandioso, Guerra e Paz, expõe toda essência punível da sangrenta corrente de ilhas ditando, roucamente, a epopéia dos campos de concentração do arquipélago. Agora ouça bem esse nome: Gulag (acrônimo que significa Administração Geral dos Campos, era a entidade que administrava todos os campos de trabalhos forçados da URSS), sua sintonia invoca dor. Ali o sofrimento, inclusive, desencadeia-se em perdição. Aleksandr Solzhenitsyn, o autor, experimentou a maldade do regime stalinista na pele como

I Graduando em medicina pela Universidade Federal do Sul da Bahia- UFSB. Email: negromontejeff@yahoo.com.br. 

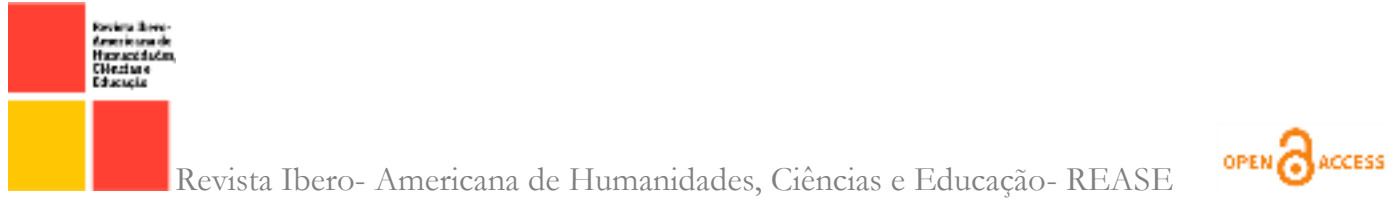

prisioneiro de um dos inúmeros campos de trabalhos forçados na Sibéria, e diagnosticou a presença da falta de sentido e da agonia que carcomia o pensamento de justiça com uma foice imposta pelo sistema vigente. Gente dormia sem saber se acordaria em liberdade e ainda reconhecia que, uma vez dentro de uma daquelas inúmeras ilhas, a probabilidade de retorno era praticamente nula. Entendemos que as árticas ilhas impostas pela União das Repúblicas Socialistas Soviéticas e seu regime era uma imagem retroativa que não deixava o povo respirar. Num campo de ocasiões suprimidas, delimitavam-se particularidades que ofereceriam uma tragédia anunciada, descrita por inúmeros prisioneiros que sentenciavam, diante de correntes que pareciam inquebrantáveis, o fracasso do sistema imposto. Aleksandr Solzhenitsyn, ele próprio personagem do século, sofreu anos tumultuosos isolado no implacável frio siberiano e provavelmente se lançou em vários poços de incerteza sendo devorado, pouco a pouco, em compêndios de torturas, alienação e repugnância massificados pela violência e paranoia. Arquipélago Gulag, sendo uma coletânea de relatos de condenados políticos do sistema prisional soviético, se transforma numa fonte reveladora do universo repressivo comunista e introduz um prenúncio da ruína do iceberg soviético que produzia monstros como o coronel Eliazov, famoso por quebrar a coluna de seus interrogados, e o comissário Eziépov que matou um oficial da força aérea apenas para dormir com sua mulher por uma única noite. Agora se já viu, repare, se já reparou, análise, se já analisou, julgue. Aleksandr, fundamentado em horror, escreve, um grito avança no ar, dilacera uma parede e é tragado pela solidez de uma corrente que se alia ao ar gelado das ilhas que tendem a sufocar e promover a loucura nos prisioneiros que passam a crer que o ser humano é um movimento vertical, em plena queda, a atingir o fim irracional do profundo abismo. A república socialista do temível Josef Stálin falava abertamente de igualdade e abrangia simplesmente a estrada contrária, letal, cuja matéria-prima significava atrocidade contra seu próprio povo. Aleksandr sabia disso e denunciou ao ocidente o que realmente era a poderosa União Soviética, com seus setores brutos e fatídicos, que desenvolviam sempre mecanismos de opressão que limitavam os hábitos de tortura. Aleksandr, fadigado, continuou a sentir agonia, loucura e perseguição, mas obtendo sempre o sinal da onipresente esperança. Senão onipresente, ao menos próxima, definindo que o impossível também poderia acontecer. Desta forma, 
a tirania, promulgadora de males, que faz dialogar com as paisagens inóspitas e opressivas, seguia invadindo Aleksandr Solzhenitsyn, prisioneiro do arquipélago, até o degelo de Khruschev, quando foi finalmente libertado. 